\title{
Waiter, there's a fly in my coffee!
}

\section{Lindsay Neill, Ayeesha Taylor and Nigel Hemmington}

Lindsay Neill is an AUT senior lecturer in hospitality management, with research interests in vernacular culture, food, identity, and popular culture. Lindsay has an extensive publishing portfolio, including the coauthorship of the awardwinning text The New Zealand Chef and The Great New Zealand Pie Cart.

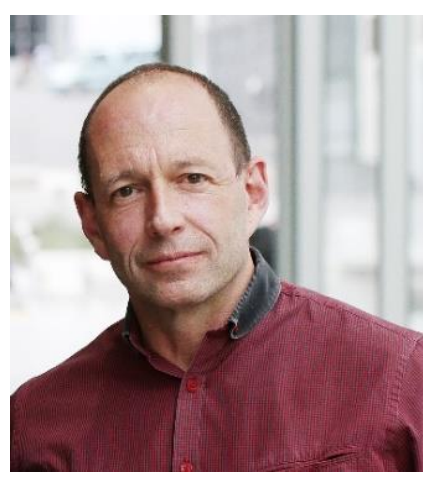

Ayeesha Taylor is completing her diploma in screen production specialising in documentary directing at Yoobee South Seas Film and Television School. Ayeesha's interest in documentary film making not only motivated the research for this paper but also provided the framework for her short documentary, Tall Poppy Chopping. As an emerging documentary film maker, Ayeesha is aware of the importance of robust
The hospitality industry is under intense pressure. COVID-19 restrictions and limited trading opportunities have forced restaurateurs to consider their pricing structures. Reflecting those concerns, Richard Corney, MD of the Inigo Coffee Group, proposed that the retail price of a cup of coffee needed to rise to between $\$ 6.50$ and $\$ 7.00$ to "take into account all the other cost increases hospitality establishments have experienced in the last decade, not to mention the challenges of the pandemic in the last two years" [1]. Alongside these revenue issues, the industry also needs to move away from a tradition of low pay and low value [2], and perhaps towards the concept of a 'hospitable wage' [3]. However, laudable as these goals might be, upward price movement may be resisted by many customers.

So how can restaurateurs and hoteliers 'sell' revised-price-products to their customers? Clearly, increased revenue can be achieved through both marginal price increases and up-selling to increase average customer spend. We propose that both of these goals can be achieved if employers embrace the concept of hospitality as an experience [4,5], where the performance of staff is central [6], and where the experience is delivered with 'hospitality personality'.

Much has been written about the personality of hospitality staff. Most of that work can be traced back to the early work of Erving Goffman [7] who proposed that hospitality employees were playing roles, and acting out, by using their emotional intelligence. Goffman likened such workers to actors who literally 'take on' a character. The characteristics of the hospitality personality have been explored by many authors [8-10] and include, agreeableness, extroversion, openness to experience, conscientiousness, and emotional stability; although some research also reveals that neuroticism is also a hospitality characteristic in hotel receptionists. Alongside this research, other studies have identified the role of mood and personality in positive guest experiences, specifically service quality perception and customer satisfaction [11]. This supports our suggestion that the performance of staff can have a direct impact on customer experience and potentially revenue, and that Corney's price recommendation could be a realistic option for many businesses struggling economically.

But there's a 'fly in the ointment': the Tall Poppy Syndrome. Tall poppy syndrome originated around 500BC in ancient Rome, when King Tarquinius Superbus demonstrated how the nation should deal with its enemies. In an active display he lopped off the heads of the tallest poppies in his garden with 
research. This paper is Ayeesha's first academic publication.

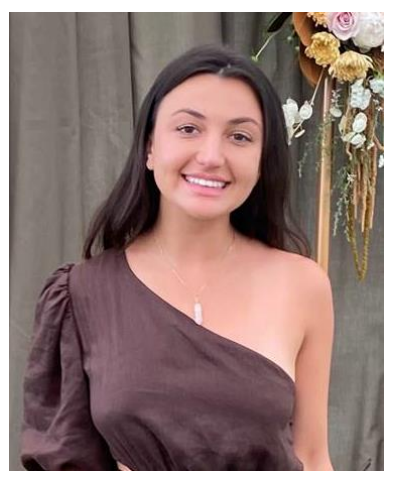

Nigel Hemmington is an active researcher in tourism and hospitality marketing with a particular interest in consumer behaviour, hospitality and tourism experience, and the concept of hospitality as a commercial phenomenon. He has published over 100 research papers and presented keynote speeches at over 50 international conferences.

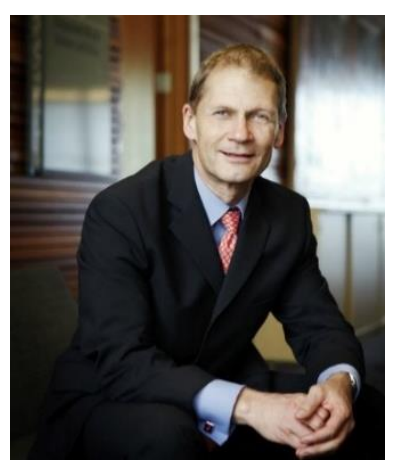

a stick [12]. Today, tall poppies are conspicuously successful people, who may attract envy, resentment or hostility, and the Tall Poppy Syndrome (TPS) is the habit of others to diminish those who have attained excellence in a field - to cut them down to size [13]. While TPS is commonly associated with Australia and New Zealand, it is also part of other cultures. Within Scandinavian cultures, janteloven ${ }^{1}$ promotes humility and conformity paralleling TPS [15]; in Japanese culture, 'the nail that sticks up gets pounded down' [16]; and within Filipino culture a crab mentality exists whereby crabs in a bucket tend to pull back any adventurous crabs trying to escape [17]. TPS is often described as being ingrained in New Zealand culture [18] and has been identified as a phenomenon in New Zealand entrepreneurship and business [19].

While TPS encourages conformist cultures, our research provides a valuable insight into how employers can spot potential employees who actively resist notions of TPS's conformity and are more likely to perform to the highest levels. Using Instagram, we interviewed 1000 young self-identifying New Zealanders to explore their qualitative experiences of TPS. They identified as $68 \%$ female and $32 \%$ male. Their age ranges were: $58 \%$ aged $18-24 ; 27 \%$ aged $25-34 ; 7 \%$ aged $35-44 ; 3 \%$ aged $45-54$; and $2 \%$ aged 55 or above. Three percent of the respondents were excluded from our final sample because they were aged 17 or younger.

The respondents' feelings, victimhood, self-esteem, and knowledge about TPS provided our research with the largest amount of data. Of our 1000 participants, $50 \%$ knew what TPS was, while $50 \%$ did not. Similarly, $45 \%$ of our respondents claimed to be victims of TPS. Contrastingly, 55\% had no experiences of TPS. Within those considerations, the data revealed clearly that TPS was perceived by participants as 'something done to them' and not as 'something they do to other people'. Yet, and despite that difference, the pervasive nature of TPS within Kiwi socio-culture was noted by participants.

Several participants recounted the cost of TPS; for example, "Definitely held me back. It can knock your confidence so much" and "Made me want to hidelplay down my talents/my life." Other participants perceived TPS "put-downs" (belittling or humiliating remarks) as a challenge or motivating force. They commented, "Uncomfortable but it pushed me harder to be even more successful" and "It motivated me. I realized people saw something in me and strived to continue improving."

For the $45 \%$ of our participants directly experiencing TPS, those experiences were grounded within two base reactions. Reflecting that, more than half of our participants adopted conformist behaviours, succumbing to the bullying pressures of others. However, $45 \%$ recognised TPS and its bullying as a motivator to create further behaviours and actions of excellence.

The role of social media in TPS was significant. Participants directly linked TPS to social media with $89 \%$ of respondents recognising the role of social media in TPS. Key to their views was the realisation that social media not only provided distance between people but also that people used social media to manipulate the image they projected to others. In those ways, social media was a mediating factor. As participants observed, "Easier to be mean and cut someone down through a comment than to their face" and "Social media has made it easier to abuse and put down those that stand out."

Given the attributes of the hospitality personality, and Richard Corney's proposed pricing restructures in hospitality, the key is for employers to 
consider the resilience of their staff to TPS and conformity. They should consider whether they can recruit and retain the $45 \%$ of staff that use TPS as inspiration to succeed - the staff who will rise the challenge of delivering exceptional customer experiences through their own performance of the 'hospitality personality'. It is within the unique characteristics of these staff that hospitality businesses can generate that extra point of difference and experience that customers will be happy to pay a little more to enjoy; and perhaps hospitality businesses might go a step further by also considering the concept of the 'hospitable wage'.

\section{Corresponding author}

Lindsay Neill can be contacted at: lindsay.neill@aut.ac.nz

\section{Note}

1. "Janteloven (the law of Jante) at its simplest describes the way that all Norwegians (and in fact, other Scandinavians too) behave: putting society ahead of the individual, not boasting about individual accomplishments, and not being jealous of others" [14].

\section{References}

(1) Wilkes, M. We Need to Pay $\$ 7$ for a Flat White if Cafes are Going to Survive, Says Coffee Boss, 2021. https://www.stuff.co.nz/life-style/food-drink/drinks/127196374/weneed-to-pay-7-for-a-flat-white-if-cafes-are-going-to-survive-says-coffee-boss (accessed Dec 12, 2021).

(2) Te Ora, N. Does Hospitality Have a Low Wages Problem? Workers Say Yes. Some $\begin{array}{llll}\text { Restaurant Owners Say } & \text { No, }\end{array}$ https://www.stuff.co.nz/business/industries/125301113/does-hospitality-have-a-lowwages-problem-workers-say-yes-some-restaurant-owners-say-no (accessed Dec 10, 2021).

(3) Douglas, J.; Williamson, D.; Harris, C. Dirty Deeds Done Dirt Cheap: Creating “Hospitable Wages" through the Living Wage Movement. Hospitality E Society 2020, 10 (1), 3-22.

(4) Hemmington, N. From Service to Experience: Understanding and Defining the Hospitality Business. The Service Industries Journal 2007, 27 (6), 747-755.

(5) Lugosi, P. Hospitality Spaces, Hospitable Moments: Consumer Encounters and Affective Experiences in Commercial Settings. Journal of Foodservice 2008, 19 (2), 139-149.

(6) Morgan, M.; Watson, P.; Hemmington, N. Drama in the Dining Room: Theatrical Perspectives on the Foodservice Encounter. Journal of Foodservice 2008, 19 (2), 111-118.

(7) Goffman, E. The Presentation of Self in Everyday Life; Doubleday: Garden City, New York, 1959.

(8) Köşker, H.; Unur, K.; Gursoy, D. The Effect of Basic Personality Traits on Service Orientation and Tendency to Work in the Hospitality and Tourism Industry. Journal of Teaching in Travel \& Tourism 2019, 19 (2), 140-162.

(9) Grobelna, A. Extraversion and its Importance in the Hospitality Workplace. Scientific Journal, No. 876, Economic Problems of Tourism 2015, 3 (31), 89-96.

(10) Gonzalez-Gonzalez, T.; García-Almeida, D. J. Frontline Employee-Driven Change in Hospitality Firms: An Analysis of Receptionists' Personality on Implemented Suggestions. International Journal of Contemporary Hospitality Management 2021, 33 (12), $4439-4459$. 
(11) Kocabulut, Ö.; Albayrak, T. The Effects of Mood and Personality Type on Service Quality Perception and Customer Satisfaction. International Journal of Culture, Tourism, and Hospitality Research 2019, 13 (1), 98-112.

(12) Felton, D. Advice to Tyrants: The Motif of "Enigmatic Counsel" in Greek and Roman Texts. Phoenix 1998, 52 (1-2), 42-54.

(13) Feather, N. T. Attitudes towards the High Achiever: The Fall of the Tall Poppy. Australian Journal of Psychology 1989, 41 (3), 239-267.

(14) Nikel, D. What Exactly Is Janteloven? Life in Norway, 2015. https://www.lifeinnorway.net/what-exactly-is-janteloven/ (accessed Dec 10, 2021).

(15) Ahlness A. Janteloven and Social Conformity in Thorbørn Egner's Literature, 2014. http://ncurproceedings.org/ojs/index.php/NCUR2014/article/view/738 (accessed Oct 8, 2019)

(16) Matsumoto, D. Culture and Self: An Empirical Assessment of Markus and Kitayama's Theory of Independent and Interdependent Self-Construals. Asian Journal of Social Psychology 1999, 2, 289-310.

(17) Licuanan, P. A Moral Recovery Program: Building a People - Building a Nation. In: Dy, M. B. (ed) Values in Philippine Culture and Education: Philippine Philosophical Studies, 1; The Council for Research in Values and Philosophy: Washington, DC, 1994, pp. 3554.

(18) Ockhuysen, S. It's Time to Do Better and Cut Tall Poppy Syndrome out of Our Culture. Stuff, Feb 20, 2020. https://www.stuff.co.nz/taranaki-dailynews/news/119627156/its-time-to-do-better-and-cut-tall-poppy-syndrome-out-of-ourculture (accessed Dec 11, 2021)

(19) Kirkwood, J. Tall Poppy Syndrome: Implications for Entrepreneurship in New Zealand. Journal of Management \& Organization 2007, 13 (4), 366-382. 